\author{
O.A.Tarasova ${ }^{1}$, A.V.Vasilyev ${ }^{2}$, V.B.Vasilyev ${ }^{1, *}$ \\ ${ }^{1}$ Belgorod State National Research University, Belgorod, Russia; \\ ${ }^{2}$ OOO "Severgrup", Moscow, Russia \\ (E-mail: tarasova_o@bsu.edu.ru,alexvassel@gmail.com,vladimir.b.vasilyev@gmail.com)
}

\title{
On Discrete Solutions for Elliptic Pseudo-Differential Equations
}

\begin{abstract}
We consider discrete analogue for simplest boundary value problem for elliptic pseudo-differential equation in a half-space with Dirichlet boundary condition in Sobolev-Slobodetskii spaces. Based on the theory of discrete boundary value problems for elliptic pseudo-differential equations we give a comparison between discrete and continuous solutions for certain model boundary value problem.
\end{abstract}

Keywords: Digital pseudo-differential operator, Discrete solution, Discrete boundary value problem, Rate of approximation.

\section{Introduction}

As soon as boundary value problems for partial differential equations were formulated, then at the same time the necessity of solving methods has appeared. Since finding exact solution for these problems is a very seldom phenomenon, numerical and approximate methods are extensively used. According to development of computer technologies, a preference is given to such methods which can be easily realized by computers.

There are a lot of approximate methods for solving boundary value problems in mathematical literature (see, for example, classical books [1-4] and many others) All authors consider a priori given boundary value problem and construct for it certain approximate structures. As a rule this way leads to final system of linear algebraic equations and the solution of the latter system us declared as an approximate solution for the starting problem.

In our opinion there is a reason to study discrete objects initially and then to apply their properties for studying approximation of starting continuous objects. This approach was started from papers [5-10] and further it was developed in [11-15]. We based on Eskin's approach for elliptic model pseudo-differential equations in a half-space [5] and have developed appropriate discrete theory. This report is devoted to a special case how we can approximate the infinite discrete objects by finite ones.

\section{Digital Operators and Discrete Equations}

We will use the following notations. Let $\mathbf{T}^{m}$ be $m$-dimensional cube $[-\pi, \pi]^{m}, h>0, \hbar=h^{-1}$. We will consider all functions defined in the cube as periodic functions in $\mathbf{R}^{m}$ with the same cube of periods.

If $u_{d}(\tilde{x}), \tilde{x} \in h \mathbf{Z}^{m}$ is a function of a discrete variable, then we call it "discrete function". For such discrete functions one can define the discrete Fourier transform

$$
\left(F_{d} u_{d}\right)(\xi) \equiv \tilde{u}_{d}(\xi)=\sum_{\tilde{x} \in h \mathbf{Z}^{m}} e^{-i \tilde{x} \cdot \xi} u_{d}(\tilde{x}) h^{m}, \quad \xi \in \hbar \mathbf{T}^{m},
$$

if the latter series converges, and the function $\tilde{u}_{d}(\xi)$ is a periodic function on $\mathbf{R}^{m}$ with the basic cube of periods $\hbar \mathbf{T}^{m}$. This discrete Fourier transform preserves basic properties of the integral Fourier transform, particularly the inverse discrete Fourier transform is given by the formula

$$
\left(F_{d}^{-1} \tilde{u}_{d}\right)(\tilde{x})=\frac{1}{(2 \pi)^{m}} \int_{\hbar \mathbf{T}^{m}} e^{i \tilde{x} \cdot \xi} \tilde{u}_{d}(\xi) d \xi, \quad \tilde{x} \in h \mathbf{Z}^{m} .
$$

${ }^{*}$ Corresponding author.

E-mail: vladimir.b.vasilyev@gmail.com 
Let $\mathbf{T}^{m}=[-\pi, \pi]^{m}, h>0, A_{d}(\xi), \xi \in \mathbf{R}^{m}$ be a periodic function with basic cube of periods $\hbar \mathbf{T}^{m}, D \subset \mathbf{R}^{m}$ be a domain. We introduce a digital pseudo-differential operator

$$
\left(A_{d} u_{d}\right)(\tilde{x})=\sum_{\tilde{y} \in h \mathbf{Z}^{m}} \int_{\hbar \mathbf{T}^{m}} A_{d}(\xi) e^{i(\tilde{y}-\tilde{x}) \cdot \xi} u_{d}(\tilde{y}) d \xi h^{m}, \quad \tilde{x} \in D_{d} \equiv D \cap h \mathbf{Z}^{m},
$$

which is defined for functions of a discrete variable $\tilde{x} \in h \mathbf{Z}^{m}$.

We study operator equations

$$
A_{d} u_{d}=v_{d}
$$

its solvability and approximate properties for small $h$.

Let us denote $\zeta^{2}=h^{-2} \sum_{k=1}^{m}\left(e^{-i h \cdot \xi_{k}}-1\right)^{2}, S\left(h \mathbf{Z}^{m}\right)$ is a discrete analogue of the Schwartz space $S\left(\mathbf{R}^{m}\right)$ [7] and introduce the following:

Definition 1. The space $H^{s}\left(h \mathbf{Z}^{m}\right)$ is a closure of the space $S\left(h \mathbf{Z}^{m}\right)$ with respect to the norm

$$
\left\|u_{d}\right\|_{s}=\left(\int_{\hbar \mathbf{T}^{m}}\left(1+\left|\zeta^{2}\right|\right)^{s}\left|\tilde{u}_{d}(\xi)\right|^{2} d \xi\right)^{1 / 2} .
$$

Further, let $D \subset \mathbf{R}^{m}$ be a domain, and $D_{d}=D \cap h \mathbf{Z}^{m}$ be a discrete domain.

Definition 2. The space $H^{s}\left(D_{d}\right)$ consists of discrete functions from $H^{s}\left(h \mathbf{Z}^{m}\right)$ which supports belong to $\overline{D_{d}}$. A norm in the space $H^{s}\left(D_{d}\right)$ is induced by a norm of the space $H^{s}\left(h \mathbf{Z}^{m}\right)$. The space $H_{0}^{s}\left(D_{d}\right)$ consists of discrete functions $u_{d}$ with a support in $D_{d}$, and these discrete functions should admit a continuation into the whole $H^{s}\left(h \mathbf{Z}^{m}\right)$. A norm in the $H_{0}^{s}\left(D_{d}\right)$ is given by the formula

$$
\left\|u_{d}\right\|_{s}^{+}=\inf \left\|\ell u_{d}\right\|_{s}
$$

where infimum is taken over all continuations $\ell$.

Of course, all such norms are equivalent to the $L_{2}$-norm but this equivalence depends on $h$. Let us note that all constants below in our considerations do not depend on $h$.

To study the equation (1) in a discrete half-space $\left(D=\mathbf{R}_{+}^{m} \equiv\left\{x \in \mathbf{R}^{m}: x-\left(x^{\prime}, x_{m}\right), x_{m}>0\right\}\right)$ we use a special factorization for the symbol $A_{d}(\xi)$

$$
A_{d}(\xi)=A_{d,+}(\xi) \cdot A_{d,-}(\xi)
$$

where the factors $\tilde{A}_{ \pm}(\xi)$ admit a holomorphic continuation into half-strips $\hbar \Pi_{ \pm}$,

$$
\Pi_{ \pm}=\left\{z \in \mathbf{C}: z=\xi_{m}+i \tau, \xi_{m} \in\left[-h^{-1} \pi, h^{-1} \pi\right], \pm \tau>0\right\} .
$$

with respect to the last variable $\xi_{m}$ under fixed $\left(\xi_{1}, \cdots, \xi_{m-1}\right) \in \hbar \mathbf{T}^{m-1}$ and satisfy some estimates [1-3].

\section{Discrete Equations}

We consider the class $E_{\alpha}$, which includes symbols satisfying the following condition

$$
c_{1}\left(1+\left|\zeta^{2}\right|\right)^{\alpha / 2} \leq\left|A_{d}(\xi)\right| \leq c_{2}\left(1+\left|\zeta^{2}\right|\right)^{\alpha / 2}
$$

with universal positive constants $c_{1}, c_{2}$ non-depending on $h$ and the symbol $A_{d}(\xi)$.

Definition 3. Periodic factorization of an elliptic symbol $A_{d}(\xi) \in E_{\alpha}$ is called its representation in the form

$$
A_{d}(\xi)=A_{d,+}(\xi) A_{d,-}(\xi)
$$

where the factors $A_{d, \pm}(\xi)$ admit an analytical continuation into half-strips $\hbar \Pi_{ \pm}$on the last variable $\xi_{m}$ for almost all fixed $\xi^{\prime} \in \hbar \mathbf{T}^{m-1}$ and satisfy the estimates

$$
\left|A_{d,+}^{ \pm 1}(\xi)\right| \leq c_{1}\left(1+\left|\hat{\zeta}^{2}\right|\right)^{ \pm \frac{\infty}{2}}, \quad\left|A_{d,-}^{ \pm 1}(\xi)\right| \leq c_{2}\left(1+\left|\hat{\zeta}^{2}\right|\right)^{ \pm \frac{\alpha-\infty}{2}},
$$


with constants $c_{1}, c_{2}$ non-depending on $h$,

$$
\hat{\zeta}^{2} \equiv \hbar^{2}\left(\sum_{k=1}^{m-1}\left(e^{-i h \xi_{k}}-1\right)^{2}+\left(e^{-i h\left(\xi_{m}+i \tau\right)}-1\right)^{2}\right), \quad \xi_{m}+i \tau \in \hbar \Pi_{ \pm} .
$$

The number $æ \in \mathbf{R}$ is called an index of periodic factorization.

Such a representation can be constructed effectively and it fully determines a solvability picture for the equation (1).

\section{Conditions for a Unique Solvability}

Some auxiliaries Firstly, for an elliptic symbol $A_{d}(\xi)$ such periodic factorization exists always $[5,8]$.

Secondly, the index $æ$ of periodic factorization determines how much additional conditions for the solution $u_{d}$ or for the right hand side $v_{d}$ we need $[7,9]$.

Thirdly, the equation (1) is uniquely solvable in the discrete half-space $H^{s}\left(D_{d}\right)$ for arbitrary right hand side $v_{d} \in H_{0}^{s-\alpha}\left(D_{d}\right)$ only under the condition

$$
|æ-s|<1 / 2,
$$

Kernel of elliptic digital operator in a discrete half-space

In this paper we consider more complicated case when the condition (2) does not hold. There are two possibilities in this situation, and we consider one case which leads to typical boundary value problems. We use the following result from [7] in a simplest form.

Theorem 1. Let $æ-s=n+\delta, n \in \mathbf{N},|\delta|<1 / 2$. Then the Fourier image for a kernel of the operator $A_{d}$ consists of the following functions

$$
\tilde{u}_{d}(\xi)=\tilde{A}_{d,+}^{-1}(\xi) \sum_{k=0}^{n-1} c_{k}\left(\xi^{\prime}\right) \hat{\zeta}_{m}^{k}
$$

where $c_{k}\left(\xi^{\prime}\right), k=0,1, \cdots, n-1$, are arbitrary functions from $H^{s_{k}}\left(h \mathbf{T}^{m-1}\right), s_{k}=s-\Re+k-1 / 2$.

The a priori estimate

$$
\left\|u_{d}\right\|_{s} \leq a \sum_{k=0}^{n-1}\left[c_{k}\right]_{s_{k}}
$$

holds, where $[\cdot]_{s_{k}}$ denotes a norm in the space $H^{s_{k}}\left(h \mathbf{T}^{m-1}\right)$, and the constant $a$ does not depend on $h$.

\section{Discrete Structures as Approximating Objects.}

Initial Observations for $D=\mathbf{R}^{m}$. Here and below we consider model pseudo-differential operators with symbols $A(\xi)$ satisfying the condition

$$
c_{1}(1+|\xi|)^{\alpha} \leq|A(\xi)| \leq c_{2}(1+|\xi|)^{\alpha} .
$$

Further, the symbol $A_{d}(\xi)$ will be defined in the following way. We take a restriction of $A(\xi)$ on the cube $\hbar \mathbf{T}^{m}$ and periodically extend it onto a whole $\mathbf{R}^{m}$. We consider such operator as an approximate operator for $A$. For arbitrary function $u$ the notation $Q_{h} u$ will denote the same construction. So, to find an approximate discrete solution for the equation

$$
(A u)(x)=v(x), \quad x \in D,
$$

for $D=\mathbf{R}^{m}$ we can use the following discrete equation

$$
A_{d} u_{d}=Q_{h} v .
$$

Its solution is given by the formula

$$
u_{d}(\tilde{x})=\frac{1}{(2 \pi)^{m}} \int_{\hbar \mathbf{T}^{m}} e^{i \tilde{x} \cdot \xi} A^{-1}(\xi) \tilde{v}(\xi) d \xi, \quad \tilde{x} \in h \mathbf{Z}^{m},
$$

so that we do not need to find an approximate solution for an infinite system of linear algebraic equations. For our case we need to apply any kind of cubature formulas for calculating the latter integral and a cubature formula for calculating the Fourier transform $\tilde{v}(\xi)$. For $v \in S\left(\mathbf{R}^{m}\right)$ the discrete solution $u_{d}(\tilde{x})$ tends to $u(\tilde{x})$ very fast under $h \rightarrow 0$ [12]. 


\section{Rate of Approximation.}

Infinite Discrete Half-Space Case. Here we consider the case $æ-s=1+\delta,|\delta|<1 / 2$. According to Theorem 1 , the kernel of the operator $A_{d}$ includes only one arbitrary function so that we need only one additional condition.

The continuous analogue of the discrete boundary value problem

$$
\begin{gathered}
\left(A_{d} u_{d}\right)(\tilde{x})=0, \quad \tilde{x} \in D_{d}, \\
u_{d}\left(\tilde{x}^{\prime}, 0\right)=g_{d}\left(x^{\prime}\right), \quad \tilde{x}^{\prime} \in h \mathbf{Z}^{m-1},
\end{gathered}
$$

is the following

$$
\begin{gathered}
(A u)(x)=0, \quad x \in \mathbf{R}_{+}^{m}, \\
u\left(x^{\prime}, 0\right)=g\left(x^{\prime}\right), \quad x^{\prime} \in \mathbf{R}^{m-1},
\end{gathered}
$$

where $A$ is a pseudo-differential operator with symbol $A(\xi)$. To obtain some comparison between discrete and continuous solutions we will remind how the continuous solution looks. If the index of factorization equals to $æ$ and $æ-s=1+\delta,|\delta|<1 / 2$ then the unique solution for the problem (5),(6) is constructed by the similar formula

$$
\tilde{u}(\xi)=b^{-1}\left(\xi^{\prime}\right) \tilde{g}\left(\xi^{\prime}\right) A_{+}^{-1}\left(\xi^{\prime}, \xi_{m}\right),
$$

where $A_{ \pm}\left(\xi^{\prime}, \xi_{m}\right)$ are elements of factorization of the symbol $A(\xi)$ [5],

$$
b\left(\xi^{\prime}\right)=\int_{-\infty}^{+\infty} A_{+}^{-1}\left(\xi^{\prime}, \xi_{m}\right) d \xi_{m},
$$

assuming that $b\left(\xi^{\prime}\right) \neq 0, \forall \xi^{\prime} \in \mathbf{R}^{m-1}$. Let us note that this is simplest variant of Shapiro-Lopatinskii condition [5].

We have the following discrete solution [8]

$$
\begin{gathered}
\tilde{u}_{d}(\xi)=b_{d}^{-1}\left(\xi^{\prime}\right) \tilde{g}_{d}\left(\xi^{\prime}\right) A_{d,+}^{-1}\left(\xi^{\prime}, \xi_{m}\right), \\
b_{d}\left(\xi^{\prime}\right)=\int_{-\hbar \pi}^{+\hbar \pi} A_{d,+}^{-1}\left(\xi^{\prime}, \xi_{m}\right) d \xi_{m},
\end{gathered}
$$

in which we choose special approximations. We take $g_{d}=Q_{h} g$ and $A_{d, \pm}\left(\xi^{\prime}, \xi_{m}\right)$ we take as restrictions of $A_{ \pm}\left(\xi^{\prime}, \xi_{m}\right)$ on $\hbar \mathbf{T}^{m}$. Then the periodic symbol

$$
A_{d}(\xi)=A_{d,+}\left(\xi^{\prime}, \xi_{m}\right) A_{d,-}\left(\xi^{\prime}, \xi_{m}\right)
$$

satisfies all conditions of periodic factorization with the same index $æ$. Moreover, $\tilde{g}_{d}\left(\xi^{\prime}\right)$ and $A_{d,+}\left(\xi^{\prime}, \xi_{m}\right)$ coincide with $\tilde{g}\left(\xi^{\prime}\right)$ and $A_{+}\left(\xi^{\prime}, \xi_{m}\right)$ respectively on $\hbar \mathbf{T}^{m}$.

Theorem 2. Let $æ>1, s>m / 2, g \in H^{s-1 / 2}\left(\mathbf{R}^{m-1}\right)$. A comparison between solutions of problems (3), (4) and (5), (6) is given in the following way

$$
\left|u(\tilde{x})-u_{d}(\tilde{x})\right| \leq C h^{\infty-1}, \quad \tilde{x} \in h \mathbf{Z}^{m} .
$$

Proof. We need to compare two integrals:

$$
u(\tilde{x})=\frac{1}{(2 \pi)^{m}} \int_{\mathbf{R}^{m}} e^{i \tilde{x} \cdot \xi} b^{-1}\left(\xi^{\prime}\right) \tilde{g}\left(\xi^{\prime}\right) A_{+}^{-1}\left(\xi^{\prime}, \xi_{m}\right) d \xi
$$

and

$$
u_{d}(\tilde{x})=\frac{1}{(2 \pi)^{m}} \int_{\hbar \mathbf{T}^{m}} e^{i \tilde{x} \cdot \xi} b_{d}^{-1}\left(\xi^{\prime}\right) \tilde{g}\left(\xi^{\prime}\right) A_{+}^{-1}\left(\xi^{\prime}, \xi_{m}\right) d \xi
$$

for $\tilde{x} \in h \mathbf{Z}^{m}$. 
Thus, we have

$$
\begin{gathered}
u(\tilde{x})-u_{d}(\tilde{x})=\frac{1}{(2 \pi)^{m}} \int_{\hbar \mathbf{T}^{m}} e^{i \tilde{x} \cdot \xi}\left(b^{-1}(\xi)-b_{d}^{-1}\left(\xi^{\prime}\right)\right) \tilde{g}\left(\xi^{\prime}\right) A_{+}^{-1}\left(\xi^{\prime}, \xi_{m}\right) d \xi+ \\
\frac{1}{(2 \pi)^{m}} \int_{\mathbf{R}^{m} \backslash \hbar \mathbf{T}^{m}} e^{i \tilde{x} \cdot \xi} b^{-1}\left(\xi^{\prime}\right) \tilde{g}\left(\xi^{\prime}\right) A_{+}^{-1}\left(\xi^{\prime}, \xi_{m}\right) d x i i,
\end{gathered}
$$

because the functions $\tilde{g}, \tilde{g}_{d}$ and $A_{+}, A_{d,+}$ coincide in $\hbar \mathbf{T}^{m}$.

Now we estimate the second integral.

$$
\begin{gathered}
\int_{\mathbf{R}^{m} \backslash \hbar \mathbf{T}^{m}} e^{i \tilde{x} \cdot \xi} b^{-1}\left(\xi^{\prime}\right) \tilde{g}\left(\xi^{\prime}\right) A_{+}^{-1}\left(\xi^{\prime}, \xi_{m}\right) d \xi\left|\leq \operatorname{const} \int_{\mathbf{R}^{m} \backslash \hbar \mathbf{T}^{m}}\right| \tilde{g}\left(\xi^{\prime}\right)|| A_{+}^{-1}\left(\xi^{\prime}, \xi_{m}\right) \mid d \xi \leq \\
\text { const } \int_{\mathbf{R}^{m-1} \backslash \hbar \mathbf{T}^{m-1}}\left|\tilde{g}\left(\xi^{\prime}\right)\right|\left(\int_{-\infty}^{-\hbar \pi}+\int_{\hbar \pi}^{+\infty}\right)\left|A_{+}^{-1}\left(\xi^{\prime}, \xi_{m}\right)\right| d \xi_{m} d \xi^{\prime} .
\end{gathered}
$$

Further, we estimate

$$
\begin{gathered}
\left(\int_{-\infty}^{-\hbar \pi}+\int_{\hbar \pi}^{+\infty}\right)\left|A_{+}^{-1}\left(\xi^{\prime}, \xi_{m}\right)\right| d \xi_{m} \leq \mathrm{const} \int_{\hbar \pi}^{+\infty}\left(1+\left|\xi^{\prime}\right|+\left|\xi_{m}\right|\right)^{-\infty} d \xi_{m}= \\
\frac{\text { const }}{æ-1}\left(1+\left|\xi^{\prime}\right|+\hbar \pi\right)^{1-æ} \leq c_{6} h^{æ-1} .
\end{gathered}
$$

Now by Cauchy-Schwartz inequality we have

$$
\begin{aligned}
& \int_{\mathbf{R}^{m-1} \backslash \hbar \mathbf{T}^{m-1}}\left|\tilde{g}\left(\xi^{\prime}\right)\right| d \xi^{\prime} \leq \\
& \left(\int_{\mathbf{R}^{m-1} \backslash \hbar \mathbf{T}^{m-1}}\left|\tilde{g}\left(\xi^{\prime}\right)\right|^{2}\left(1+\left|\xi^{\prime}\right|\right)^{2 s-1} d \xi^{\prime}\right)^{1 / 2}\left(\int_{\mathbf{R}^{m-1} \backslash \hbar \mathbf{T}^{m-1}}\left(1+\left|\xi^{\prime}\right|\right)^{-2 s+1} d \xi^{\prime}\right)^{1 / 2} .
\end{aligned}
$$

Since $g \in H^{s-1 / 2}\left(\mathbf{R}^{m-1}\right)[5]$ the first factor is less than $[g]_{s-1 / 2}$ and the second one tends to zero if $s>m / 2$. For the first integral we use the estimate

$$
\left|b^{-1}\left(\xi^{\prime}\right)-b_{d}^{-1}\left(\xi^{\prime}\right)\right| \leq \text { const } \cdot h^{æ-1}
$$

(see [15]).

Finally,

$$
\begin{gathered}
\left|\frac{1}{(2 \pi)^{m}} \int_{\hbar \mathbf{T}^{m}} e^{i \tilde{x} \cdot \xi}\left(b^{-1}(\xi)-b_{d}^{-1}\left(\xi^{\prime}\right)\right) \tilde{g}\left(\xi^{\prime}\right) A_{+}^{-1}\left(\xi^{\prime}, \xi_{m}\right) d \xi\right| \leq \\
\text { const } \cdot h^{æ-1} \int_{\hbar \mathbf{T}^{m}}\left|\tilde{g}\left(\xi^{\prime}\right)\right|\left|A_{+}^{-1}\left(\xi^{\prime}, \xi_{m}\right)\right| d \xi \leq \text { const } \cdot h^{æ-1} \int_{\hbar \mathbf{T}^{m-1}} \frac{\left|\tilde{g}\left(\xi^{\prime}\right)\right|}{\left(1+\left|\xi^{\prime}\right|\right)^{æ-1}} d \xi^{\prime}
\end{gathered}
$$

and further as above using Cauchy-Schwartz inequality.

Finite Truncation. To obtain finite object for calculation we can apply an arbitrary cubature formula for the integral (7) and to approximately find its value in nodal points. 


\section{Conclusion}

Here only model operators in a half-space were considered. We hope that these ideas and technique will be useful for more complicated situations in which both an operator depends on a spatial variable or a domain is not a half-space.

\section{Acknowledgements}

This work was supported by the State contract of the Russian Ministry of Education and Science (contract No FZWG-2020-0029).

\section{References}

1 Strang, G., \& Fix, G. (2008). An analysis of the finite element method. Cambridge Wellesley-Cambridge Press, 2 edition.

2 Samarskii, A.A. (2001). The theory of difference schemes. CRC Press Boca Raton.

3 Ryaben'kii, V.S. (2002). Method of difference potentials and its applications. Springer-Verlag, BerlinHeidelberg.

4 Hsiao, G., \& Wendland, W.(2008). Boundary integral equations. Springer-Verlag, Berlin-Heidelberg.

5 Eskin, G. (1981). Boundary value problems for elliptic pseudodifferential equations. AMS Providence.

6 Vasilev, A.V., \& Vasilev, V.B. (2015). Periodic Riemann problem and discrete convolution equations. Differ. Equ., 51(5), 652-660.

7 Vasilyev, A.V., \& Vasilyev, V.B. (2018). Pseudo-differential operators and equations in a discrete halfspace. Math. Model. Anal., 23(3), 492-506.

8 Vasilyev, A.V., \& Vasilyev, V.B. (2018). On some discrete boundary value problems in canonical domains. Differential and Difference Equations and Applications. ICDDEA, Amadora, Portugal, Springer Proc. Math. \& Stat., 230, 569-579.

9 Vasilyev, A.V., \& Vasilyev, V.B. (2018). On some discrete potential like operators. Tatra Mt.Math. Publ., 71, 195-212.

10 Vasilyev, V.B.(2017). Discreteness, periodicity, holomorphy and factorization. Integral Methods in Science and Engineering. V.1, Theoretical Technique, 315-324.

11 Vasilyev, A., \& Vasilyev, V. (2019). Digital operators, discrete equations and error estimates. Numerical Mathematics and Advanced Applications ENUMATH LNCSE, 126, 983-991.

12 Vasilyev, V.B. (2019). Digital approximations for pseudo-differential equations and error estimates. Numerical Methods and Applications. NMA LNCS, 11189, 483-490.

13 Vasilyev, V.B. (2019). On a digital Version of pseudo-differential operators and its applications. Finite Difference Methods. Theory and Applications. FDM LNCS, 11386, 596-603.

14 Vasilyev, V.(2017).The periodic Cauchy kernel, the periodic Bochner kernel, and discrete pseudo-differential operators. AIP Conf. Proc., 1863, 140014.

15 Tarasova, O.A., \& Vasilyev, V.B. (2019). To the theory of discrete boundary value problems. 4open, 2, $1-7$. 


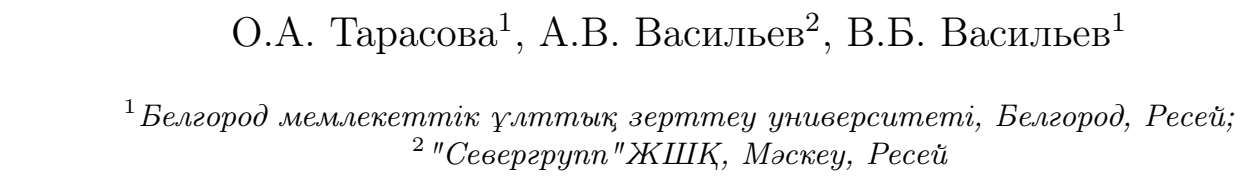

\title{
Эллиптикалық псевдодифференциалды теңдеулердің дискретті шешімдері туралы
}

\begin{abstract}
Соболев-Слободецкий кеңістігіндегі Дирихле шекаралық жағдайы бар жартылай кеңістіктегі эллиптикалық псевдодифференциалды теңдеудің қарапайым шекаралық есебінің дискретті аналогы қарастырылған. Эллиптикалық псевдодифференциалды теңдеулер үшін дискретті жиек есептері теориясына сүйене отырып, бір модельдік шекаралық есеп үшін дискретті және үздіксіз шешімдер арасындағы салыстыру берілген.
\end{abstract}

Kiлm сөздер: дискретті псевдодифференциалды оператор, дискретті шешім, дискретті шекаралық есеп, жуықтау реті.

\section{О.А. Тарасова ${ }^{1}$, А.В. Васильев ${ }^{2}$, В.Б. Васильев ${ }^{1}$}

${ }^{1}$ Белгородский государственный националъный исследователъский университет, Белгород, Россия; ${ }^{2} \mathrm{OOO}$ «евергрупп», Москва, Россия

\section{О дискретных решениях эллиптических псевдодифференциальных уравнений}

\footnotetext{
Рассмотрен дискретный аналог простейшей краевой задачи для эллиптического псевдодифференциального уравнения в полупространстве с граничным условием Дирихле в пространстве СоболеваСлободецкого. Основываясь на теории дискретных краевых задач для эллиптических псевдодифференциальных уравнений, дано сравнение между дискретными и непрерывными решениями для одной модельной краевой задачи.

Ключевые слова: дискретный псевдодифференциальный оператор, дискретное решение, дискретная краевая задача, порядок аппроксимации.
} 